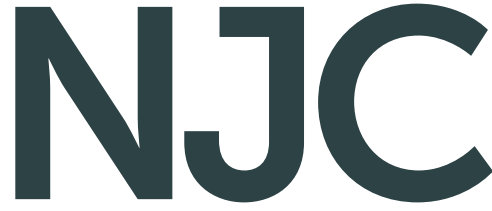

New Journal of Chemistry rsc.li/njc
A journal for new directions in chemistry

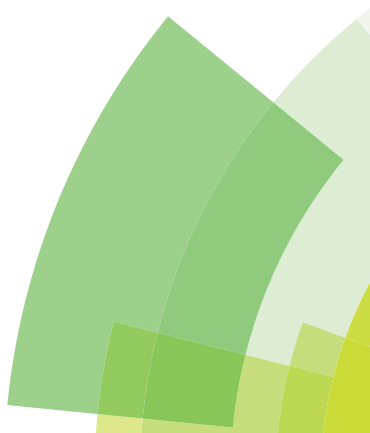

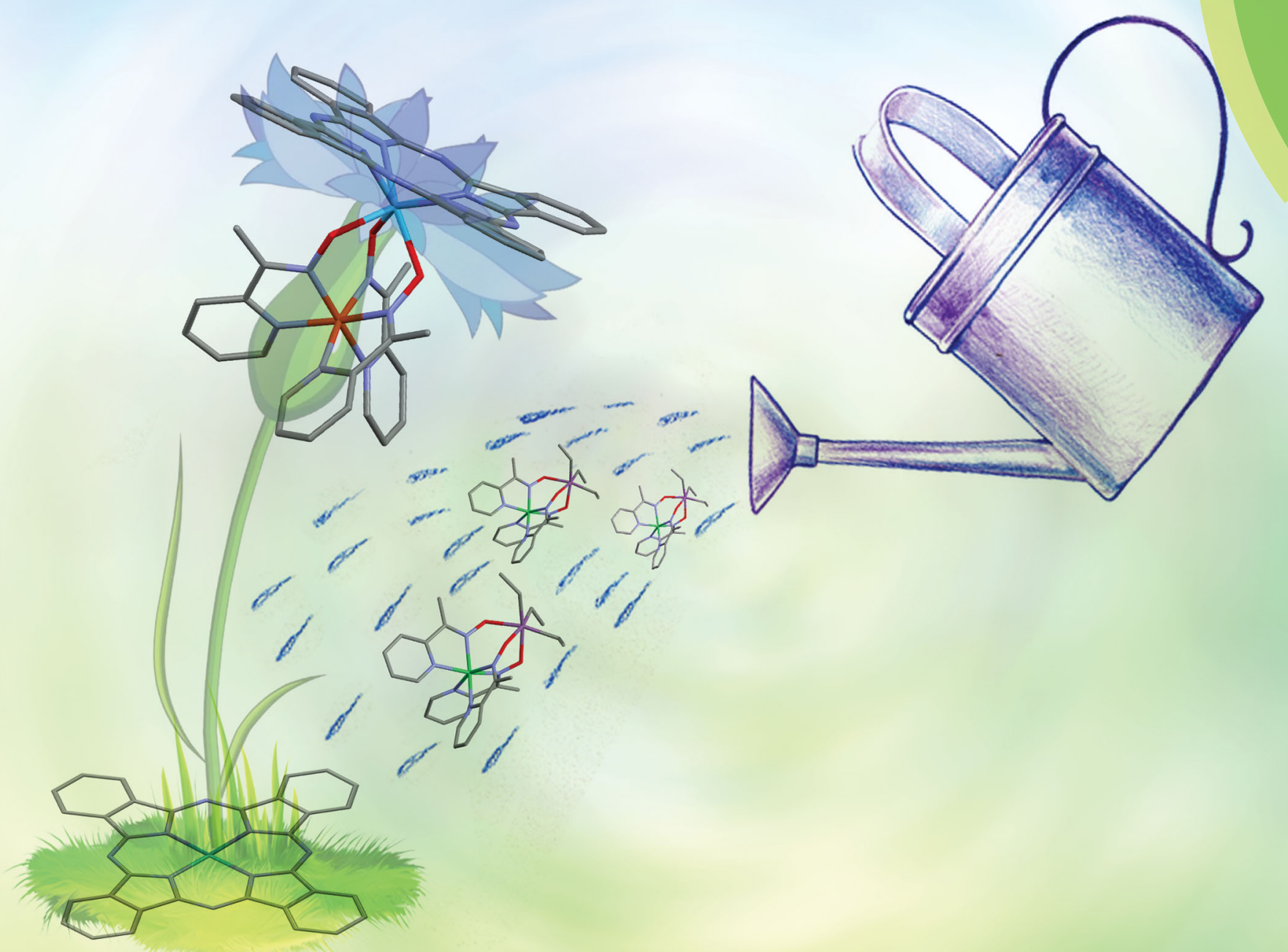

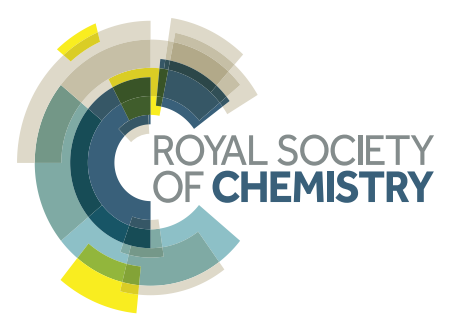




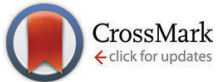

Cite this: New J. Chem., 2017, 41,3251

Received 11th January 2017, Accepted 6th March 2017 DOI: 10.1039/c7nj00131b rsc.li/njc

\title{
Synthesis, X-ray structure and electrochemical properties of hybrid binuclear metallophthalocyaninate-capped tris-pyridineoximates $\dagger$
}

\author{
Semyon V. Dudkin, ${ }^{a}$ Alexander S. Belov, ${ }^{a}$ Yulia V. Nelyubina, ${ }^{a}$ Anastasia V. Savchuk, ${ }^{b}$ \\ Alexander A. Pavlov, ${ }^{a}$ Valentin V. Novikov ${ }^{a}$ and Yan Z. Voloshin ${ }^{\text {ac }}$
}

\begin{abstract}
New antimony-capped iron and nickel(॥) tris-pyridineoximates with a labile triethylantimony cross-linking group were obtained by template condensation of 2-acetylpyridinoxime with triethylantimony(v) dibromide on the corresponding metal ion as a matrix. They easily undergo transmetallation (capping group exchange) with Lewis-acidic zirconium and hafnium(IV) phthalocyaninates (PC) to give binuclear MPc-capped trispyridineoximates. The obtained hybrid complexes and their precursors were thoroughly characterized (among others, by single-crystal X-ray diffraction), and their redox properties were studied by cyclic and differential pulse voltammetry.
\end{abstract}

\section{Introduction}

Macrobicyclic cage complexes with an encapsulated metal ion (clathrochelates) $^{1}$ are a special case of coordination compounds with unusual physicochemical properties. ${ }^{2}$ Owing to this, these cage complexes have found use as electrocatalysts for hydrogen evolution $^{1 b, 3}$ and as prospective materials for biomedical applications, ${ }^{4}$ including topological drugs, ${ }^{5}$ anti-fibrillogenic agents, ${ }^{6}$ and selective cytotoxic compounds. ${ }^{7}$ Paramagnetic cobalt(II) clathrochelates have also been recognized as single-molecule magnets (SMMs), ${ }^{8}$ i.e. molecules able to retain their magnetization in the absence of an applied magnetic field, ${ }^{9}$ and they are expected to revolutionize the field of high-density information storage or quantum computing. Among various building blocks for the design of SMMs, porphyrins and phthalocyanines (Pcs) have been widely used. ${ }^{10}$ Therefore, hybrid molecular systems that combine a transition metal (pseudo)clathrochelate and a porphyrin or a phthalocyanine complex seem to be even more prospective candidates for manufacturing new types of SMMs.

\footnotetext{
${ }^{a}$ Nesmeyanov Institute of Organoelement Compounds of the Russian Academy of Sciences, 119991, Moscow, Russia.E-mail:voloshin@ineos.ac.ru; Tel: +7 4991359344

${ }^{b}$ Vernadskii Institute of General and Inorganic Chemistry of the National Academy of Sciences of Ukraine, 03680 Kiev, Ukraine

${ }^{c}$ Gubkin Russian State University of Oil and Gas, 119991 Moscow, Russia

$\dagger$ Electronic supplementary information (ESI) available: The details of analytical and spectroscopic data collection, together with the crystallographic, UV-vis and electrochemical data. CCDC 1503088-1503092. For ESI and crystallographic data in CIF or other electronic format see DOI: 10.1039/c7nj00131b
}

In the present paper, we report a two-step approach to the first binuclear metallophthalocyaninato-capped metal(II) trispyridineoximates, representatives of a new type of hybrid polytopic and multicentered molecular system, and their antimony-capped precursors. As obtaining these complexes with a cobalt ion is still a real challenge, the proposed approach is tested here on iron and nickel(II) as the encapsulated ions. Such complexes were obtained by a transmetallation reaction (capping group exchange), which has been successfully used for the synthesis of various polyazomethine phthalocyaninato- and porphyrinoclathrochelates (Scheme 1). ${ }^{11}$

\section{Results and discussion}

While antimony-capped metal tris-pyridineoximates are rare, ${ }^{12}$ tris-dioximates of iron(II) and cobalt(III) are easy to obtain ${ }^{13}$ in moderate yields via template condensation with triethylantimony dibromide.

Here, antimony-capped iron and nickel(II) tris-pyridineoximates $\left(\left[\mathrm{Fe}(\mathrm{AcPyOx})_{3}\left(\mathrm{Sb}\left(\mathrm{C}_{2} \mathrm{H}_{5}\right)_{3}\right)\right]\left(\mathrm{ClO}_{4}\right)\right.$ and $\left.\left[\mathrm{Ni}(\mathrm{AcPyOx})_{3}\left(\mathrm{Sb}\left(\mathrm{C}_{2} \mathrm{H}_{5}\right)_{3}\right)\right]\left(\mathrm{ClO}_{4}\right)\right)$ were prepared in high yields (85 and $90 \%$, respectively) via the template self-assembly of a metal(II) salt, 2-acetypyridineoxime and triethylantimony(v) dibromide in an ethanol medium, with $\mathrm{NaHCO}_{3}$ as a base (Scheme 2). We also attempted to use triethylamine as a base; however, isolation of the target products was more challenging.

The binuclear MPc-capped hybrid derivatives of the compounds ([Fe(AcPyOx) $\left.)_{3}(\mathrm{ZrPc})\right]\left(\mathrm{ClO}_{4}\right),\left[\mathrm{Fe}(\mathrm{AcPyOx})_{3}(\mathrm{HfPc})\right]\left(\mathrm{ClO}_{4}\right)$, $\left[\mathbf{N i}\left(\mathrm{AcPyOx}_{3}(\mathbf{Z r P c})\right]\left(\mathrm{ClO}_{4}\right)\right.$ and $\left.\left[\mathrm{Ni}(\mathrm{AcPyOx})_{3}(\mathbf{H f P c})\right]\left(\mathrm{ClO}_{4}\right)\right)$ were synthesized in relatively high yields $(65-79 \%)$ by transmetallation 


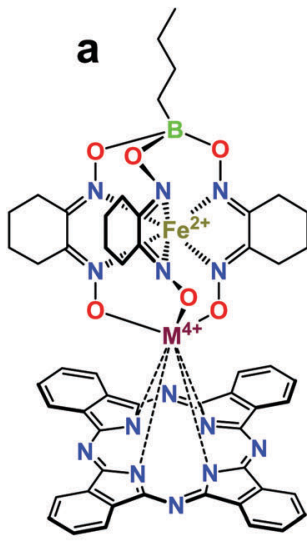

$\mathbf{M}=\mathbf{Z r}, \mathbf{H f}$

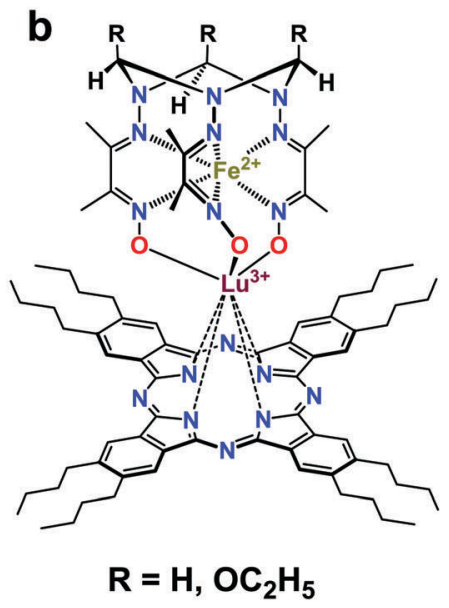

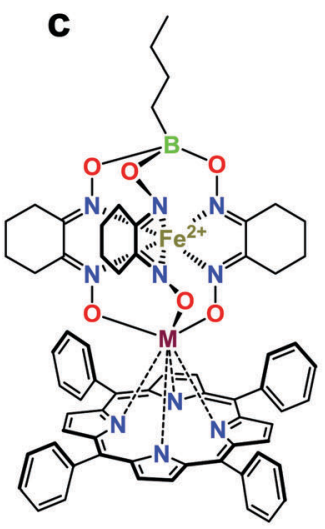

$\mathbf{M}=\mathbf{Z r}, \mathbf{H f}$

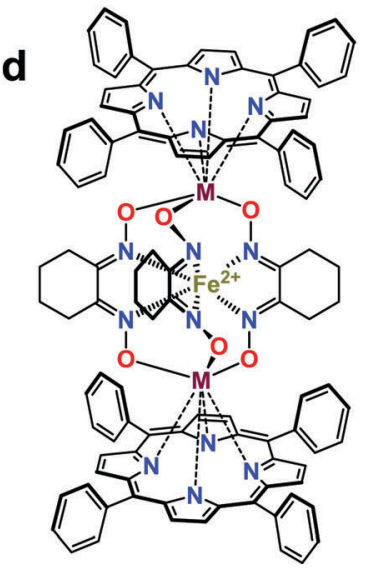

$M=\mathbf{Z r}, \mathbf{H f}$

Scheme 1 Hybrid iron(I) phthalocyaninato- (a and b) and porphyrinoclathrochelates (c and d).
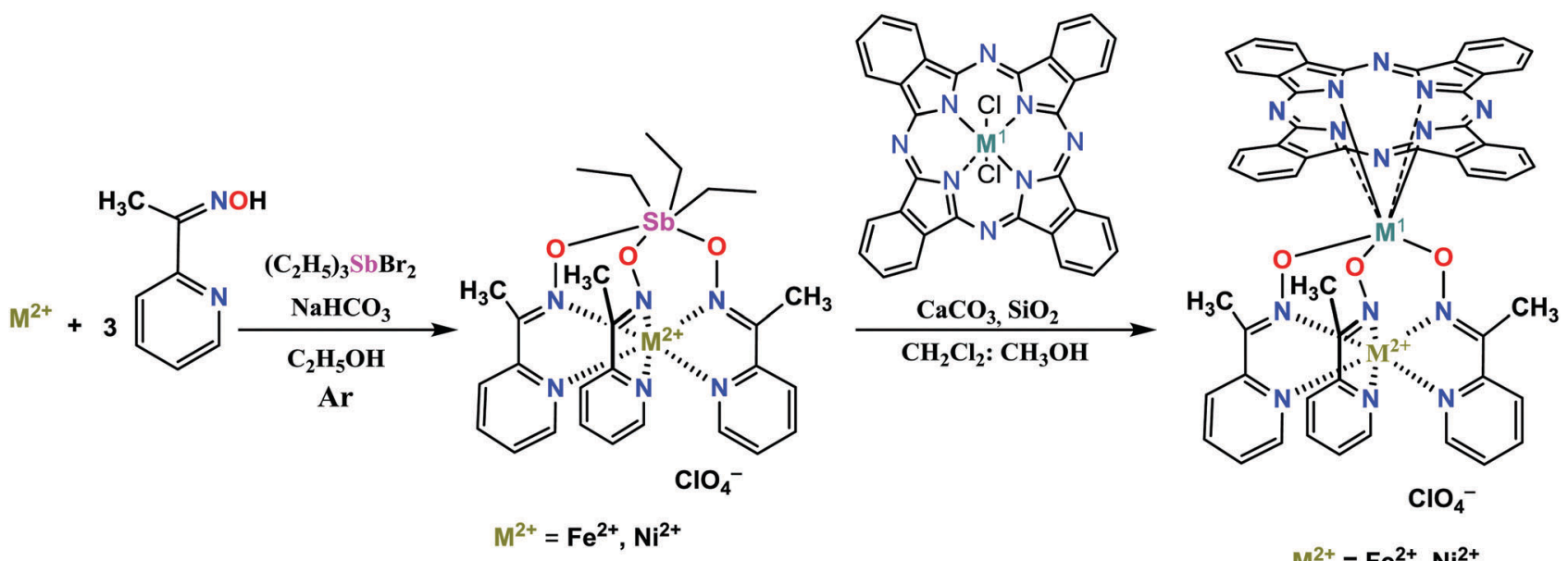

$\mathrm{M}^{2+}=\mathrm{Fe}^{2+}, \mathrm{Ni}^{2+}$,
$\mathrm{M}^{1}=\mathrm{Zr}^{4+}, \mathrm{Hf}^{4+}$

Scheme 2 Synthesis of antimony-capped iron and nickel(॥) tris-pyridineoximates and their binuclear $\mathrm{M}^{\prime \mathrm{V}} \mathrm{Pc}$-capped hybrid derivatives.

of the above antimony(v)-capped precursors under mild reaction conditions (with a methanol-dichloromethane mixture as a solvent and at ambient temperature) using equimolar amounts of Lewis-acidic zirconium and hafnium(rv) phthalocyaninates (Scheme 2).

The formation of these new metallophthalocyaninato-capped tris-pyridineoximates was confirmed by elemental analysis, 1D $\left({ }^{1} \mathrm{H}\right.$ and $\left.{ }^{13} \mathrm{C}\left\{{ }^{1} \mathrm{H}\right\}\right)$ and 2D NMR, MALDI-TOF MS, UV-vis spectra and single-crystal X-ray diffraction; their redox properties were studied by cyclic (CV) and differential pulse (DPV) voltammetry.

Introduction of the Pc fragment into $\left[\mathrm{Fe}(\mathbf{A c P y O x})_{3}\left(\mathbf{S b E t}_{3}\right)\right] \mathbf{C l O}_{4}$ affects the ${ }^{1} \mathrm{H}$ and ${ }^{13} \mathrm{C}\left\{{ }^{1} \mathrm{H}\right\}$ NMR spectra of the resulting phthalocyaninatoclathrochelates $\left[\mathrm{Fe}(\mathbf{A c P y O x})_{3}(\mathbf{H f P c})\right]$ and $\left[\mathrm{Fe}(\mathbf{A c P y O x})_{3^{-}}\right.$ (ZrPc)]: the signals of the protons of the methyl group and those of the pyridine ring shift to higher values by 2.5 and $1.0 \mathrm{ppm}$, respectively, as these nuclei are located in the shielding region of the $\pi$-electron current in the conjugated macrocyclic system. The signals of the nuclei of all the carbon atoms in $\left[\mathbf{F e}(\mathbf{A c P y O x})_{3}(\mathbf{H f P c})\right]$ and $\left[\mathrm{Fe}(\mathbf{A c P y O x})_{3}(\mathrm{ZrPc})\right]$ are shifted towards the low-field region by $\sim 1 \mathrm{ppm}$ for the same reason (see the ESI, $\dagger$ Fig. S1, S2, and S5-S8). As the chemical properties of zirconium and hafnium are similar, the values of the chemical shifts for $\left[\mathrm{Fe}(\mathbf{A c P y O x})_{3}(\mathbf{H f P c})\right]$ and [Fe(AcPyOx $\left.)_{3}(\mathrm{ZrPc})\right]$, and $\left[\mathbf{N i}(\mathbf{A c P y O x})_{3}(\mathbf{H f P c})\right]$ and $\left[\mathbf{N i}(\mathbf{A c P y O x})_{3}(\mathrm{ZrPc})\right]$ differ only slightly. A similar behavior has been observed earlier for other zirconiumand hafnium(Iv)-capped phthalocyaninatoclathrochelates. ${ }^{11 a, c}$

The antimony-cross-linked nickel(II) complex [Ni(AcPyOx) $)_{3}$ $\left.\left(\mathbf{S b}\left(\mathrm{C}_{2} \mathbf{H}_{5}\right)_{3}\right)\right]\left(\mathrm{ClO}_{4}\right)$ and its $\mathrm{M}^{\mathrm{IV}}$ Pc-capped derivatives [Ni(AcPyOx $)_{3^{-}}$ $(\mathbf{H f P c})](\mathbf{C l O 4})$ and $\left[\mathrm{Ni}(\mathrm{AcPyOx})_{3}(\mathrm{ZrPc})\right]\left(\mathrm{ClO}_{4}\right)$ are paramagnetic compounds $(s=1)$ owing to the $d^{8}$ high-spin configuration of the nickel(II) ion. Their NMR spectra (see the ESI, $\dagger$ Fig. S3, S4, S9 and S10) are thus dominated by paramagnetic effects: contact shifts that depend on the spin density distribution in a molecule and pseudocontact shifts that are associated with dipole-dipole electronnucleus interactions. As the paramagnetic shifts reach several hundred ppm, they mask the effect of the $\pi$-electron current.

Like the earlier reported phenylboron-capped iron(II) trispyrazoloximates with a similar distribution of unpaired electrons, ${ }^{14}$ 

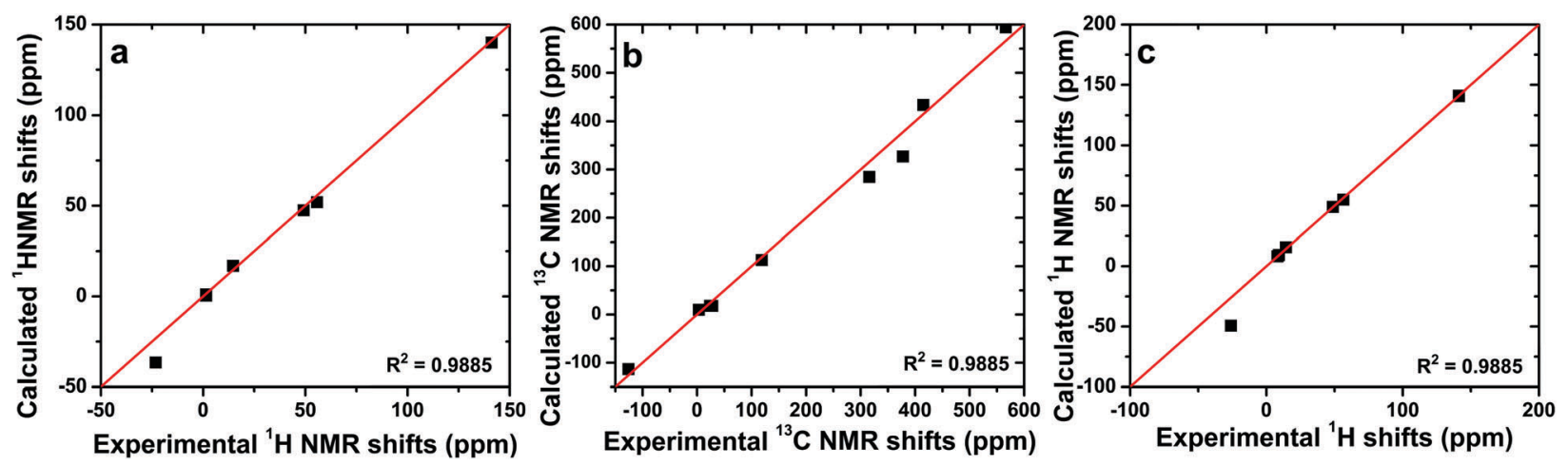

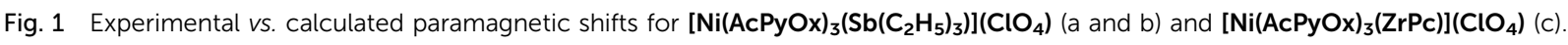

the trigonal-prismatic nickel(II) complexes are expected to have a very small pseudocontact contribution due to the orbitally non-degenerate ground state. Therefore, their NMR spectra are mainly determined by the contact shifts, so assignment of the signals in these spectra is nontrivial and was successfully completed only when assisted by DFT calculations of the complexes $\left[\mathrm{Ni}(\mathrm{AcPyOx})_{3}\left(\mathrm{Sb}\left(\mathrm{C}_{2} \mathrm{H}_{5}\right)_{3}\right)\right]\left(\mathrm{ClO}_{4}\right)$ and $\left[\mathrm{Ni}(\mathrm{AcPyOx})_{3}(\mathrm{ZrPc})\right]\left(\mathrm{ClO}_{4}\right)$. For $\left[\mathrm{Ni}(\mathrm{AcPyOx})_{3}(\mathrm{ZrPc})\right]\left(\mathrm{ClO}_{4}\right)$ and $\left[\mathrm{Ni}(\mathrm{AcPyOx})_{3}\left(\mathrm{HfPc}_{3}\right)\right]\left(\mathrm{ClO}_{4}\right)$, the paramagnetic broadening of these signals prevented us from obtaining their ${ }^{13} \mathrm{C}$ NMR spectra.

Additionally, the excellent agreement between the experimental paramagnetic shifts and the calculated contact shifts (Fig. 1) confirmed the relatively low importance of the pseudocontact shifts. Note that the paramagnetic nickel(II) ion affects the ${ }^{1} \mathrm{H}$ NMR shifts of the protons of the Pc-fragments only slightly, as the contact shift becomes negligible when the nucleus under question and the paramagnetic center are separated by five or more chemical bonds.

MALDI-TOF mass spectra of all the complexes obtained contain the intensive peaks of the corresponding cationic species $\left[\mathrm{M}-\mathrm{ClO}_{4}^{-}\right]^{+}$. UV-vis spectra of $\left[\mathrm{Fe}(\mathrm{AcPyOx})_{3}(\mathbf{Z r P c})\right]\left(\mathrm{ClO}_{4}\right)$, $\left[\mathrm{Fe}(\mathrm{AcPyOx})_{3}(\mathrm{HfPc})\right]\left(\mathrm{ClO}_{4}\right), \quad\left[\mathrm{Ni}(\mathrm{AcPyOx})_{3}(\mathrm{ZrPc})\right]\left(\mathrm{ClO}_{4}\right)$ and $\left[\mathrm{Ni}(\mathrm{AcPyOx})_{3}(\mathbf{H f P c})\right]\left(\mathrm{ClO}_{4}\right)$ and their antimony-capped precursors

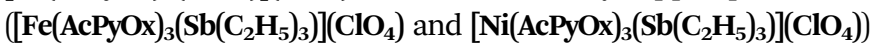
in dichloromethane are shown in Fig. 2 and Fig. S11-S17 (see the ESI $\dagger$ ). A deconvoluted spectrum of the antimony-capped iron(II)

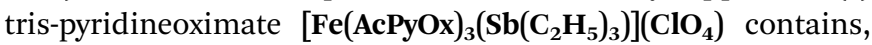
in the visible range $(440-550 \mathrm{~nm})$, four intensive $(\varepsilon \sim 2-11 \times$ $10^{3} \mathrm{~mol}^{-1} \mathrm{~L} \mathrm{~cm}^{-1}$ ) bands assigned to Fed $\rightarrow \mathrm{L} \pi^{*}$ metal-to-ligand charge transfer (MLCT). Intensive $\left(\varepsilon \sim 3-30 \times 10^{3} \mathrm{~mol}^{-1} \mathrm{~L} \mathrm{~cm}^{-1}\right)$ bands in the UV range of the spectrum were assigned to $\pi-\pi^{*}$ intraligand transitions. The UV-vis spectrum of the nickel(II)containing analogue $\left[\mathbf{N i}(\mathbf{A c P y O x})_{3}\left(\mathbf{S b}\left(\mathbf{C}_{2} \mathbf{H}_{5}\right)_{3}\right)\right]\left(\mathrm{ClO}_{4}\right)$ also contains intensive $\pi-\pi^{*}$ intraligand transition bands in the UV range. A broad asymmetrical band of low intensity $\left(\varepsilon \sim 25 \mathrm{~mol}^{-1} \mathrm{~L} \mathrm{~cm}^{-1}\right)$ is observed at $800-1000 \mathrm{~nm}$, together with more intensive ( $\varepsilon \sim 115-260 \mathrm{~mol}^{-1} \mathrm{~L} \mathrm{~cm}^{-1}$ ) bands with maxima from 400 to $500 \mathrm{~nm}$. These bands were assigned to $\mathrm{d}-\mathrm{d}$ transitions characteristic of a six-coordinate nickel(II) ion.

The UV-vis spectra of the $\mathrm{M}^{\mathrm{IV}} \mathrm{Pc}$-capped hybrid tris-pyridineoximates can be superposed on the corresponding spectra of

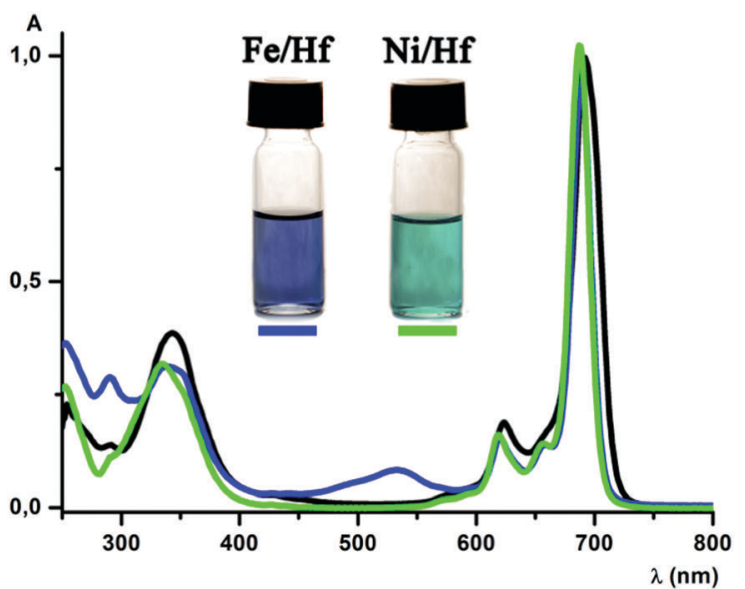

Fig. 2 UV-vis spectra of the parent phthalocyaninate $\mathrm{Hf}\left(\mathrm{Cl}_{2}\right) \mathrm{Pc}$ in DMSO (in black) and its hybrid derivatives $\left[\mathrm{Fe}(\mathrm{AcPyOx})_{3}(\mathrm{HfPc})\right]\left(\mathrm{ClO}_{4}\right)$ (in blue) and $\left[\mathrm{Ni}(\mathrm{AcPyOx})_{3}(\mathrm{HfPc})\right]\left(\mathrm{ClO}_{4}\right)$ (in green) in dichloromethane.

the metal(Iv) phthalocyaninate and metal(II) tris-pyridineoximate chromophores. In particular, the spectrum of the hybrid iron(II) complex $\left.\left[\mathbf{F e}\left(\mathrm{AcPyOx}_{3}\right)_{3} \mathbf{H f P c}\right)\right]\left(\mathrm{ClO}_{4}\right)$ (Fig. 2) contains one intensive absorption band in the red and near-IR region at $689 \mathrm{~nm}$ $\left(\varepsilon \sim 205 \times 10^{3} \mathrm{~mol}^{-1} \mathrm{~L} \mathrm{~cm}^{-1}\right)$, and its two vibronic satellites are found at $660 \mathrm{~nm}\left(\varepsilon \sim 28 \times 10^{3} \mathrm{~mol}^{-1} \mathrm{~L} \mathrm{~cm}^{-1}\right)$ and $620 \mathrm{~nm}$ $\left(\varepsilon \sim 32 \times 10^{3} \mathrm{~mol}^{-1} \mathrm{~L} \mathrm{~cm}^{-1}\right)$. In addition, there is also a broad intensive $\left(\varepsilon \sim 65 \times 10^{3} \mathrm{~mol}^{-1} \mathrm{~L} \mathrm{~cm}^{-1}\right)$ band, characteristic of the Pc fragment, at $340 \mathrm{~nm}$. A broad band observed at $534 \mathrm{~nm}$ $\left(\varepsilon \sim 16 \times 10^{3} \mathrm{~mol}^{-1} \mathrm{~L} \mathrm{~cm}^{-1}\right)$ was assigned to the Fed $\rightarrow \mathrm{L} \pi^{*}$ MLCT in the iron(II)-containing tris-pyridineoximate fragment. The UV-vis spectrum of the $\left[\mathrm{Fe}(\mathbf{A c P y O x})_{3}(\mathbf{Z r P c})\right]\left(\mathbf{C l O}_{4}\right)$ complex is identical to that of its hafnium cross-linked analogue (see the ESI, $\dagger$ Fig. S15).

The spectrum of the hybrid complex [ $\mathbf{N i}\left(\mathrm{AcPyOx}_{\mathbf{3}}(\mathbf{H f P c})\right]\left(\mathrm{ClO}_{\mathbf{4}}\right)$ contains one intensive $\left(\varepsilon \sim 243 \times 10^{3} \mathrm{~mol}^{-1} \mathrm{~L} \mathrm{~cm}^{-1}\right)$ band in the red and near-IR region at $688 \mathrm{~nm}$ and its two vibronic satellites: a shoulder at $656 \mathrm{~nm}\left(\varepsilon \sim 34 \times 10^{3} \mathrm{~mol}^{-1} \mathrm{~L} \mathrm{~cm}^{-1}\right)$ and a band at $619 \mathrm{~nm}\left(\varepsilon \sim 39 \times 10^{3} \mathrm{~mol}^{-1} \mathrm{~L} \mathrm{~cm}^{-1}\right)$. A broad B band of the metal(Iv)-containing Pc fragment appears as a band at $335 \mathrm{~nm}$ $\left(\varepsilon \sim 78 \times 10^{3} \mathrm{~mol}^{-1} \mathrm{~L} \mathrm{~cm}^{-1}\right)$ with a shoulder at $352 \mathrm{~nm}(\varepsilon \sim 64 \times$ $10^{3} \mathrm{~mol}^{-1} \mathrm{~L} \mathrm{~cm}^{-1}$ ) (Fig. 2). The observed splitting of this B band 
a

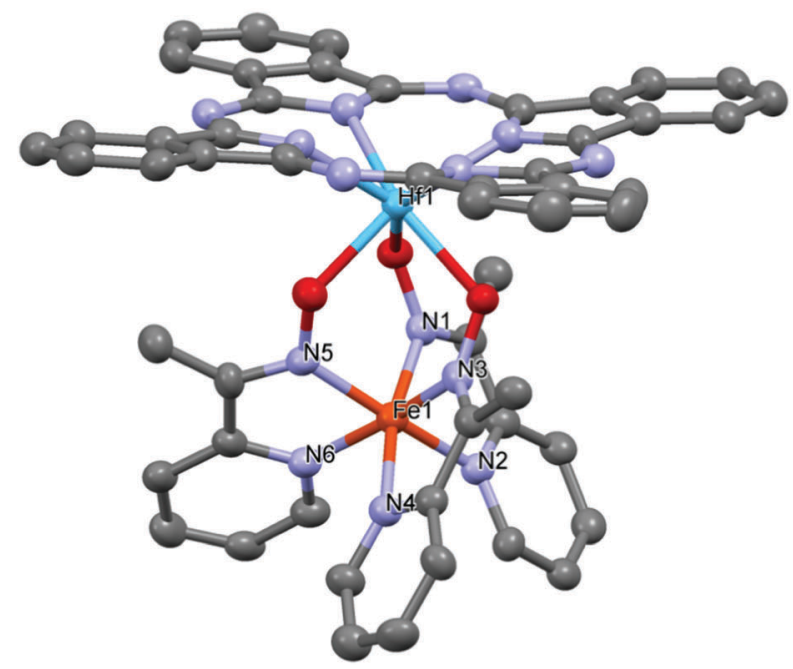

b

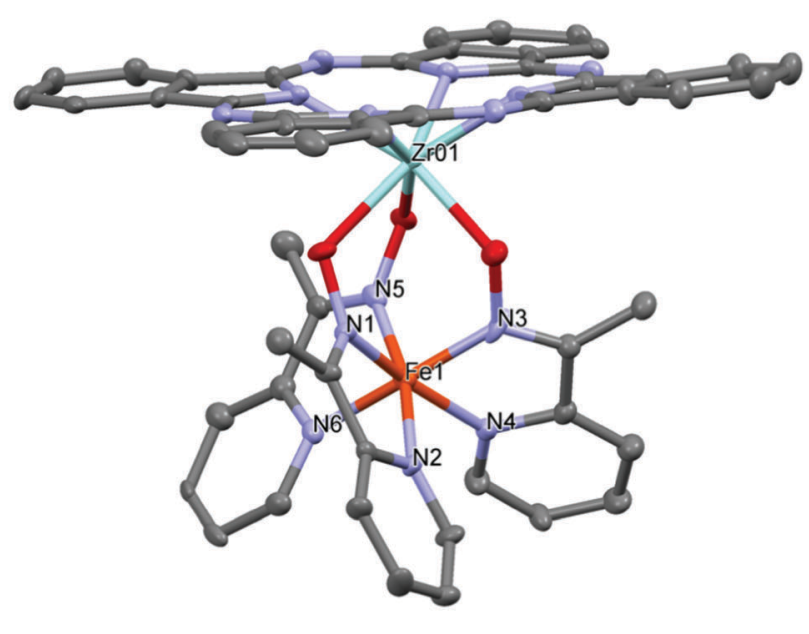

Fig. 3 General view of the hybrid tris-pyridineoximate cations $\left[\mathrm{Fe}(\mathrm{AcPyOx})_{\mathbf{3}}(\mathrm{HfPc})\right]^{+}$(a) and $\left[\mathrm{Fe}(\mathrm{AcPyOx})_{3}(\mathrm{ZrPc})\right]^{+}$(b) with atoms shown as thermal ellipsoids at $p=30 \%$; hydrogen atoms and perchlorate anions are omitted for clarity.

may be attributed to the contribution of the tris-pyridineoximate fragment. The UV-vis spectrum of the zirconium(IV) Pc-capped complex $\left[\mathbf{N i}(\mathbf{A c P y O x})_{3}(\mathbf{Z r P c})\right]\left(\mathbf{C l O}_{4}\right)$ is almost identical to that of the Hf(Iv) analogue (see the ESI, $\dagger$ Fig. S17).

The structures of the obtained hybrid complexes [Fe(AcPyOx $)_{3}$ $(\mathrm{HfPc})]\left(\mathrm{ClO}_{4}\right),\left[\mathrm{Fe}(\mathrm{AcPyOx})_{3}(\mathrm{ZrPc})\right]\left(\mathrm{ClO}_{4}\right),\left[\mathrm{Ni}(\mathrm{AcPyOx})_{3}(\mathrm{HfPc})\right]\left(\mathrm{ClO}_{4}\right)$, and $\left[\mathbf{N i}(\mathbf{A c P y O x})_{3}(\mathbf{Z r P c})\right]\left(\mathbf{C l O}_{4}\right)$ (Fig. 3 and 4 ) were confirmed by single-crystal X-ray diffraction analysis, which also allowed the structure of one of their precursors, $\left[\mathrm{Ni}(\mathrm{AcPyOx})_{3}\left(\mathrm{Sb}\left(\mathrm{C}_{2} \mathbf{H}_{5}\right)_{3}\right)\right]\left(\mathrm{ClO}_{4}\right)$, to be elucidated (Fig. S18, see the ESI $\dagger$ ). In the hybrid complexes (Table 1), the $\mathrm{M}^{\mathrm{II}} \mathrm{N}_{6}$ polyhedron adopts a geometry that is intermediate between a trigonal prism (TP, the distortion angle $\varphi=0^{\circ}$ ) and a trigonal antiprism (TAP, $\varphi=60^{\circ}$ ), and may be alternatively described as a truncated trigonal pyramid (for it has bases of a slightly different size due to the very different nature of the apical fragments). The central metal ion $\mathrm{M}^{\mathrm{II}}$ is located almost in the center of the $\mathrm{MN}_{6}$ polyhedron (Fe-N 1.860(9)-1.978(7) $\AA$; Ni-N 2.010(3)-2.112(4) $\AA$ ), as is typical of low-spin Fe(II) and high-spin $\mathrm{Ni}(\mathrm{II})$ ions, and is only slightly shifted towards the capping metal ion $\mathrm{M}^{\mathrm{IV}}$ ( $\mathrm{Zr}$ or $\mathrm{Hf}$ ) along the line $\mathrm{M}^{\mathrm{II}}-\mathrm{M}^{\mathrm{IV}}$.

The degree of TP-to-TAP distortion in the $\mathrm{M}^{\mathrm{II}} \mathrm{N}_{6}$ polyhedron depends on $\mathrm{M}^{\mathrm{II}}$ and only slightly on $\mathrm{M}^{\mathrm{IV}}$. It is much closer to TAP in the iron complexes than in their nickel analogues (Table 1); the corresponding distortion angle $\varphi$ varies from $45.3-46.4^{\circ}$ to
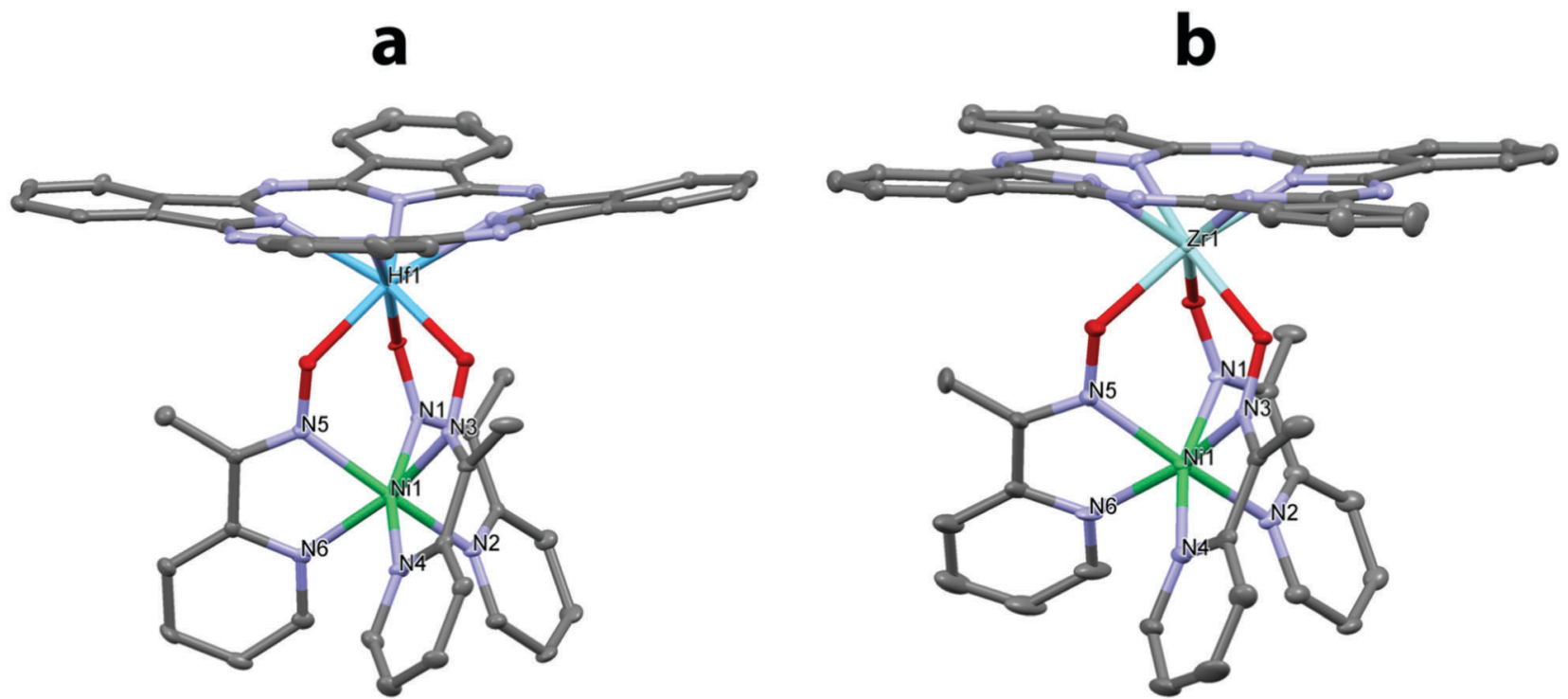

Fig. 4 General view of the hybrid tris-pyridineoximate cations $\left[\mathrm{Ni}(\mathrm{AcPyOx})_{3}(\mathrm{HfPc})\right]^{+}$(a) and $\left[\mathrm{Ni}(\mathrm{AcPyOx})_{3}(\mathrm{ZrPc})\right]^{+}$(b) with atoms shown as thermal ellipsoids at $p=30 \%$; hydrogen atoms and perchlorate anions are omitted for clarity. 
Table 1 Main geometrical parameters of the obtained hybrid complexes

\begin{tabular}{|c|c|c|c|c|}
\hline & {$\left[\mathrm{Fe}(\mathrm{AcPyOx})_{3}(\mathrm{HfPc})\right]\left(\mathrm{ClO}_{4}\right)$} & {$\left[\mathrm{Fe}(\mathrm{AcPyOx})_{3}(\mathrm{ZrPc})\right]\left(\mathrm{ClO}_{4}\right)$} & {$\left[\mathrm{Ni}(\mathrm{AcPyOx})_{3}(\mathrm{HfPc})\right]\left(\mathrm{ClO}_{4}\right)$} & {$\left[\mathrm{Ni}(\mathrm{AcPyOx})_{3}(\mathrm{ZrPc})\right]\left(\mathrm{ClO}_{4}\right)$} \\
\hline$\overline{\mathrm{M}^{\mathrm{II}} / \mathrm{M}^{\mathrm{IV}}}$ & $\mathrm{Fe} / \mathrm{Hf}$ & $\mathrm{Fe} / \mathrm{Zr}$ & $\mathrm{Ni} / \mathrm{Hf}$ & $\mathrm{Ni} / \mathrm{Zr}$ \\
\hline $\mathrm{M}^{\mathrm{II}}-\mathrm{N} 1(\AA)$ & $1.878(8)$ & $1.869(7)$ & $2.032(4)$ & $2.010(3)$ \\
\hline $\mathrm{M}^{\mathrm{II}}-\mathrm{N} 2(\AA)$ & $1.962(8)$ & $1.944(7)$ & $2.084(4)$ & $2.105(4)$ \\
\hline $\mathrm{M}^{\mathrm{II}}-\mathrm{N} 3(\AA)$ & $1.897(8)$ & $1.860(9)$ & $2.039(4)$ & $2.014(3)$ \\
\hline $\mathrm{M}^{\mathrm{II}}-\mathrm{N} 4(\AA)$ & $1.970(7)$ & $1.978(7)$ & $2.105(4)$ & $2.081(4)$ \\
\hline $\mathrm{M}^{\mathrm{II}}-\mathrm{N} 5(\AA)$ & $1.888(8)$ & $1.848(8)$ & $2.018(4)$ & $2.036(4)$ \\
\hline $\mathrm{M}^{\mathrm{II}}-\mathrm{N} 6(\AA)$ & $1.974(7)$ & $1.968(7)$ & $2.112(4)$ & $2.097(4)$ \\
\hline \multirow[t]{2}{*}{$\mathrm{N}-\mathrm{O}(\AA)$} & $1.343(9)-1.349(10)$ & $1.375(9)-1.415(10)$ & $1.352(5)-1.369(5)$ & $1.357(4)-1.365(4)$ \\
\hline & av. 1.345 & av. 1.392 & av. 1.361 & av. 1.361 \\
\hline \multirow[t]{2}{*}{$\mathrm{M}^{\mathrm{IV}}-\mathrm{O}(\AA)$} & $2.096(7)-2.126(6)$ & $2.111(6)-2.170(6)$ & $2.072(3)-2.119(3)$ & $2.114(3)-2.147(3)$ \\
\hline & av. 2.114 & av. 2.131 & av. 2.100 & av. 2.125 \\
\hline \multirow[t]{2}{*}{$\mathrm{M}^{\mathrm{IV}}-\mathrm{N}(\AA)$} & $2.219(8)-2.241(7)$ & $2.222(7)-2.244(7)$ & $2.239(4)-2.262(4)$ & $2.254(3)-2.248(3)$ \\
\hline & av. 2.230 & av. 2.233 & av. 2.250 & av. 2.249 \\
\hline \multirow[t]{2}{*}{$\mathrm{C}=\mathrm{N}(\AA)$} & $1.285(12)-1.307(12)$ & $1.276(10)-1.327(12)$ & $1.282(6)-1.293(6)$ & $1.280(6)-1.292(5)$ \\
\hline & av. 1.298 & av. 1.299 & av. 1.287 & av. 1.285 \\
\hline \multirow[t]{2}{*}{ C-C (̊) } & $1.437(15)-1.461(13)$ & $1.453(11)-1.456(12)$ & $1.466(7)-1.473(7)$ & $1.478(6)-1.492(6)$ \\
\hline & av. 1.449 & av. 1.454 & av. 1.469 & av. 1.484 \\
\hline \multirow[t]{2}{*}{$\mathrm{N}=\mathrm{C}-\mathrm{C}=\mathrm{N}\left({ }^{\circ}\right)$} & $1.1(11)-5.4(13)$ & $0.6(11)-8.1(11)$ & $4.4(7)-8.8(6)$ & $1.2(5)-7.5(5)$ \\
\hline & av. 3.8 & av. 3.4 & av. 6.4 & av. 4.0 \\
\hline$\varphi\left(^{\circ}\right)$ & 45.3 & 46.4 & 36.7 & 37.8 \\
\hline$\alpha\left({ }^{\circ}\right)$ & 80.6 & 80.2 & 77.6 & 77.4 \\
\hline$h(\AA)$ & 2.17 & 2.12 & 2.36 & 2.32 \\
\hline
\end{tabular}

36.7-37. $8^{\circ}$ with a simultaneous increase in the height of the TP-TAP polyhedron from $2.12-2.17$ to $2.32-2.36 \AA$ A. For comparison, the $\varphi$ angle of the TP-TAP polyhedron and its height in $\left[\mathbf{N i}(\mathbf{A c P y O x})_{3}\left(\mathbf{S b}\left(\mathbf{C}_{2} \mathbf{H}_{5}\right)_{3}\right)\right]\left(\mathbf{C l O}_{4}\right)$ are $35.8^{\circ}$ and $2.37 \AA$ (see the ESI, $\dagger$ Table S8). These distortions are larger than in the previously reported zirconium/hafnium-capped iron(II) Pc-clathrochelates with two capping fragments $\left(\varphi \sim 30^{\circ}\right) .{ }^{11 c, d}$ The reason for this may be the higher flexibility of the rigid caging framework in the obtained hybrid complexes, as one of their 'caps' is a perchlorate anion that is loosely bound to the pyridine moieties via weak $\mathrm{C}-\mathrm{H} \cdots \mathrm{OCl}$ contacts $(\mathrm{O} \cdots \mathrm{H}$ distance from $\sim 2.6 \AA)$. Note that similar to antimony, large zirconium and hafnium(Iv) ions are known to give clathrochelates with a more TAP-like geometry around the encapsulated metal ion $\mathrm{M}^{\mathrm{II}} \cdot{ }^{11 c}$ The average bite angle ( $\alpha$; the $\mathrm{N}-\mathrm{M}-\mathrm{N}$ angle) as well as the lengths of the $\mathrm{C}=\mathrm{N}, \mathrm{C}-\mathrm{C}$ and $\mathrm{O}-\mathrm{N}$ bonds in the caging ligand are similar in all four hybrid complexes (Table 1).

The capping metal ion $\mathrm{M}^{\mathrm{IV}}$ coordinates three oxygen atoms of the caging ligand and four nitrogen atoms of the Pc core, with only minor variations in the $\mathrm{M}^{\mathrm{IV}}-\mathrm{O}(2.072(3)-2.170(6) \AA)$ and $\mathrm{M}^{\mathrm{IV}}-\mathrm{N}(2.219(8)-2.262(4) \AA)$ bonds formed by the similarlysized heptacoordinate $\mathrm{Zr}$ (Iv) and $\mathrm{Hf}(\mathrm{Iv})$ ions (Shannon radii of 0.92 and $0.90 \AA$, respectively). In all cases, the $\mathrm{M}^{\mathrm{IV}}$ ion is displaced by approximately $1.1 \AA$ from the plane of the four nitrogen atoms it is bound to in the phthalocyanine macrocycle, which itself has a dome-like geometry. Despite this, the main supramolecular motif adopted by these hybrid complexes is a 'base-to-base' dimer produced by stacking interactions between the phthalocyanine macrocycles. The shortest $\mathrm{N} \cdots \mathrm{N}$ distance observed between the pyrrole moieties is close to $3.5 \AA$, as previously reported for zirconium/hafnium-capped iron(II) phthalocyaninatoclathrochelates with two capping fragments. ${ }^{11 c, d}$

The electrochemical properties of the obtained complexes were studied by cyclic (CV) and differential pulse (DPV) voltammetry in a dichloromethane/TBAP system (Fig. 5 and Fig. S18, ESI $\dagger$ ).

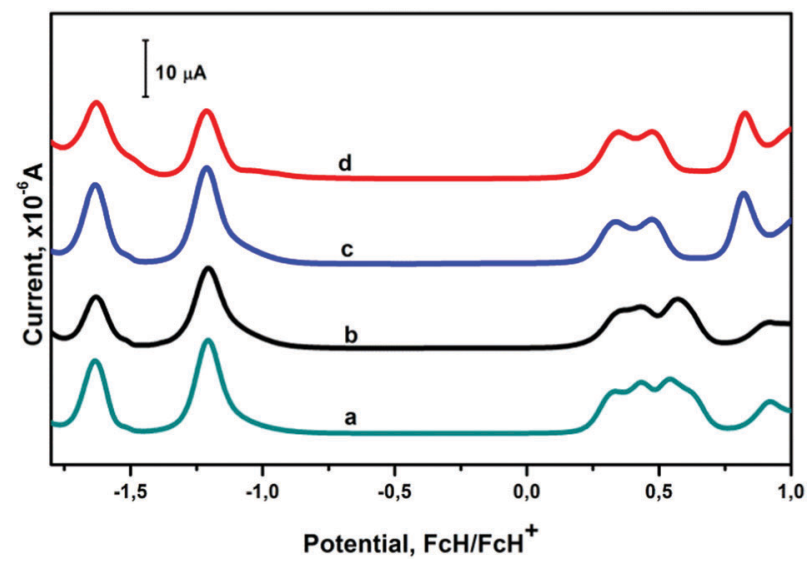

Fig. 5 DPVs for $0.1 \mathrm{mM}$ dichloromethane solutions of the complexes $\left[\mathrm{Fe}(\mathrm{AcPyOx})_{3}(\mathrm{HfPc})\right]\left(\mathrm{ClO}_{4}\right)(\mathrm{a}),\left[\mathrm{Fe}(\mathrm{AcPyOx})_{3}(\mathrm{ZrPc})\right]\left(\mathrm{ClO}_{4}\right)(\mathrm{b}),\left[\mathrm{Ni}(\mathrm{AcPyOx})_{3}-\right.$ $(\mathrm{HfPc})]\left(\mathrm{ClO}_{4}\right)(\mathrm{c})$, and $\left[\mathrm{Ni}(\mathrm{AcPyOx})_{3}(\mathrm{ZrPc})\right]\left(\mathrm{ClO}_{4}\right)(\mathrm{d})$.

For all the MPc-capped tris-pyridineoximate complexes, two subsequent reduction waves are observed in the cathodic range (see the ESI, $\dagger$ Fig. S19). These processes are quasi-reversible, as follows from $\Delta E_{\mathrm{p}}$ being in the range of $60-90 \mathrm{mV}$ and from the current ratio for the direct and reverse processes being close to 1 . The first reduction waves show diffusional control, as the peak current depends linearly on the square root of the scan rate. The potentials of these reductions are the same for all four hybrid complexes and are characteristic of Pc-centered reductions. ${ }^{11 b}$ Note that the corresponding reduction waves were absent in the CVs of the antimony-capped precursors, which do not have a Pc fragment, thus confirming this assignment.

In the anodic range, several other waves of quasi-reversible diffusionally-controlled oxidation processes were detected. Although these waves significantly overlap, DPV allowed four and three oxidation peaks to be observed for the iron and nickel(II) complexes, respectively (Fig. 5). While the very close redox potentials 
of these processes complicate the assignment of all of the peaks, the potentials of the first oxidation peaks are similar for the iron and nickel complexes and are characteristic of Pc-localized redox processes. $^{11 b}$ The second oxidation peak in the case of the iron complexes is probably due to a $\mathrm{Fe}^{2+} / \mathrm{Fe}^{3+}$ process, but the next oxidation is also localized on the Pc moiety. ${ }^{11}$ The nickel complexes, in contrast to the iron(II) complexes, show an irreversible oxidation at approximately $0.82 \mathrm{~V}\left(v s . \mathrm{Fc} / \mathrm{Fc}^{+}\right)$, assigned to a $\mathrm{Ni}^{2+/ 3+}$ process. As expected, the substitution of zirconium for hafnium does not result in any significant changes in the redox properties of the complexes. The irreversible waves, assigned to the destruction of the macrobicyclic moiety, are observed at potentials larger than -1.8 and $1.0 \mathrm{~V}\left(v s . \mathrm{Fc} / \mathrm{Fc}^{+}\right)$in the cathodic and anodic regions, respectively. This is the case for all of the compounds, including the semiclathrochelate precursors.

\section{Experimental section}

\section{Materials and physical measurements}

The reagents used $\left(\mathrm{FeCl}_{2} \cdot 4 \mathrm{H}_{2} \mathrm{O}, \mathrm{Ni}\left(\mathrm{ClO}_{4}\right)_{2} \cdot 6 \mathrm{H}_{2} \mathrm{O}, \mathrm{NaClO}_{4} \cdot \mathrm{H}_{2} \mathrm{O}\right.$, $\mathrm{NaHCO}_{3}, \mathrm{CaCO}_{3}, 2$-acetylpyridine, sorbents and solvents) were obtained commercially (SAF). The zirconium and hafnium(Iv) phthalocyaninates $\left(\mathrm{Zr}\left(\mathrm{Cl}_{2}\right) \mathrm{Pc}\right.$ and $\left.\mathrm{Hf}\left(\mathrm{Cl}_{2}\right) \mathrm{Pc}\right)$, 2-acetylpyridineoxime and triethylantimony $(\mathrm{v})$ dibromide were prepared as described earlier. $^{15}$

The analytical data for the $\mathrm{C}, \mathrm{H}$ and $\mathrm{N}$ content were obtained with a Carlo Erba model 1106 microanalyzer; the data for the $\mathrm{Sb}$ content were obtained using the X-ray fluorescence method.

MALDI-TOF mass spectra were recorded in the positive and negative ranges with a MALDI-TOF-MS Bruker Autoflex II (Bruker Daltonics) mass spectrometer in reflecto-mol mode. Ionization was induced by a UV-laser with the wavelength of $337 \mathrm{~nm}$. The samples were applied to a nickel plate, and 2,5dihydroxybenzoic acid was used as the matrix. The accuracy of the measurements was $0.1 \%$.

UV-vis spectra of all of the complexes in dichloromethane were recorded in the range of $250-800 \mathrm{~nm}$ with a Varian Cary 50 spectrophotometer. The individual Gaussian components of these spectra were calculated using the Fityk program. ${ }^{16}$

${ }^{1} \mathrm{H}$ and ${ }^{13} \mathrm{C}$ NMR spectra were recorded from $\mathrm{CD}_{2} \mathrm{Cl}_{2}$ and $\mathrm{CDCl}_{3}$ solutions of these complexes with a Bruker Avance 600 spectrometer. The measurements were done using the residual signals of $\mathrm{CD}_{2} \mathrm{Cl}_{2}\left({ }^{1} \mathrm{H} 5.32 \mathrm{ppm},{ }^{13} \mathrm{C} 54.00 \mathrm{ppm}\right)$ and $\mathrm{CDCl}_{3}$ $\left({ }^{1} \mathrm{H} 7.26 \mathrm{ppm},{ }^{13} \mathrm{C} 77.16 \mathrm{ppm}\right)$. Data acquisition and processing were performed with Topspin 2.1 and Mestrenova 9.0.0 software, respectively.

Cyclic voltammetry experiments were carried out in acetonitrile or dichloromethane solutions with $0.1 \mathrm{M}$ TBAP as a supporting electrolyte using a Metrohm Autolab PGSTAT128N potentiostat with a conventional one-compartment three-electrode cell (5 mL of solution). The platinum disk electrode (MF-2013, BASi), which was used as a working electrode, was thoroughly polished with $0.05 \mu \mathrm{m}$ alumina slurry, sonicated for two minutes in deionized water and rinsed before every measurement. A platinum wire counter electrode and standard $\mathrm{Ag} / \mathrm{AgCl} / \mathrm{NaCl}_{\mathrm{aq}}$. reference electrode (RE-5B, BASi) were used. To account for drift of the reference electrode, ferrocene was added after the measurements as an internal standard, and all of the potentials are reported relative to the $\mathrm{Fc} / \mathrm{Fc}^{+}$redox couple. The solutions were thoroughly deaerated by passing argon through them before the CV experiments and above them during the measurements.

All quantum chemical calculations were performed using the ORCA program package v. 3.0.3. ${ }^{17}$ The X-ray structures of the complexes were used as an initial approximation for geometry optimization, which was performed with the non-hybrid PBE functional $^{18}$ and the def2-TZVP basis set. ${ }^{19}$ After the geometry optimization, the tensors of hyperfine interactions for hydrogen and carbon nuclei were calculated using the hybrid PBE0 functional $^{20}$ and the def2-TZVP basis set, with the primitives of a higher order of the exponent added for a better description of the electron density around the nuclei. The paramagnetic shifts for hydrogen and carbon nuclei were calculated using the following equation: ${ }^{21}$

$$
\delta_{\mathrm{par}}=\frac{S(S+1) \mu_{\mathrm{B}}}{3 k T g_{N} \mu_{N}} \cdot g \cdot A^{\mathrm{T}}
$$

\section{Synthesis}

$\left[\mathrm{Fe}(\mathrm{AcPyOx})_{3}\left(\mathrm{Sb}\left(\mathrm{C}_{2} \mathrm{H}_{5}\right)_{3}\right)\right]\left(\mathrm{ClO}_{4}\right)$. 2-Acetylpyridineoxime $(0.41 \mathrm{~g}$, $3 \mathrm{mmol})$ and $\mathrm{FeCl}_{2} \cdot 4 \mathrm{H}_{2} \mathrm{O}(0.17 \mathrm{~g}, 0.85 \mathrm{mmol})$ were dissolved in methanol $(5 \mathrm{~mL})$ under argon, and a solution of $\left(\mathrm{C}_{2} \mathrm{H}_{5}\right)_{3} \mathrm{SbBr}_{2}$ $(0.46 \mathrm{~g}, 1.24 \mathrm{mmol})$ in methanol $(1 \mathrm{~mL})$ was added to the stirring reaction mixture. Then triethylamine $(0.53 \mathrm{~mL}, 3.8 \mathrm{mmol})$ was added dropwise to this mixture, and it was stirred for $2 \mathrm{~h}$ at room temperature and precipitated with a $\mathrm{NaClO}_{4}$ saturated aqueous solution $(15 \mathrm{~mL})$. The precipitate was filtered off, washed with water (20 mL, in two portions) and extracted with dichloromethane $(15 \mathrm{~mL})$. The dichloromethane extract was washed with water $\left(100 \mathrm{~mL}\right.$, in two portions), dried with $\mathrm{Na}_{2} \mathrm{SO}_{4}$, filtered and evaporated to dryness. The solid residue was washed with diethyl ether $(10 \mathrm{~mL})$ and dried in vacuo. Yield: $0.51 \mathrm{~g}(85 \%)$. Found (\%): $\mathrm{C}$, 42.09; H, 4.63; Fe, 7.31; Sb, 15.80. Calc. for $\mathrm{C}_{27} \mathrm{H}_{36} \mathrm{~N}_{6} \mathrm{FeClO}_{7} \mathrm{Sb}$ (\%): C, 42.11; H, 4.68; Fe, 7.28; Sb, 15.85. MS(MALDI-TOF): $m / z: 670\left[\mathrm{M}-\mathrm{ClO}_{4}{ }^{-}\right]^{+} .{ }^{1} \mathrm{H} \mathrm{NMR}\left(\mathrm{CDCl}_{3}\right): \delta(\mathrm{ppm}) 1.40\left(\mathrm{t},{ }^{3} \mathrm{~J}_{\mathrm{HH}}=\right.$ $\left.8.05 \mathrm{~Hz}, 9 \mathrm{H}, \mathrm{CH}_{3}(\mathrm{Et})\right), 1.85\left(\mathrm{~m}, 6 \mathrm{H}, \mathrm{CH}_{2}(\mathrm{Et})\right), 2.52\left(\mathrm{~s}, 9 \mathrm{H}, \mathrm{CH}_{3}\right)$, $6.93\left(\mathrm{~d},{ }^{3} J_{\mathrm{HH}}=5.37 \mathrm{~Hz}, 3 \mathrm{H}, 6-\mathrm{Py}\right), 7.37$ (m, 3H, 5-Py), 7.73 (d, $\left.{ }^{3} J_{\mathrm{HH}}=7.59 \mathrm{~Hz}, 3 \mathrm{H}, 3-\mathrm{Py}\right), 7.91$ (m, 3H, 4-Py). ${ }^{13} \mathrm{C} \mathrm{NMR}\left(\mathrm{CDCl}_{3}\right)$ : $\delta(\mathrm{ppm}) 10.58\left(\mathrm{~s}, \mathrm{CH}_{3}(\mathrm{Et})\right), 12.61\left(\mathrm{~s}, \mathrm{CH}_{3}\right), 24.18\left(\mathrm{~s}, \mathrm{CH}_{2}(\mathrm{Et})\right)$, 122.75 (s, 3-Py), 125.22 (s, 5-Py), 137.13 (s, 4-Py), 153.01 (s, 6-Py), $157.19(\mathrm{~s}, \mathrm{C}=\mathrm{N}), 158.62(\mathrm{~s}, 2-\mathrm{Py})$. UV-vis $\left(\mathrm{CH}_{2} \mathrm{Cl}_{2}\right): \lambda_{\max }$, $\mathrm{nm}\left(\varepsilon \times 10^{-3}, \mathrm{~mol}^{-1} \mathrm{~L} \mathrm{~cm}{ }^{-1}\right): 235(30), 267(2.8), 305(9.4)$, 306(19), 399(4.0), 445(2.1), 467(1.9), 498(6.7), 551(11.5).

$\left[\mathrm{Ni}(\mathrm{AcPyOx})_{3}\left(\mathrm{Sb}\left(\mathrm{C}_{2} \mathrm{H}_{5}\right)_{3}\right)\right]\left(\mathrm{ClO}_{4}\right) .2$-Acetylpyridineoxime $(0.35 \mathrm{~g}$, $2.6 \mathrm{mmol})$ was dissolved in ethanol $(5 \mathrm{~mL})$ under argon, and a solution of $\left(\mathrm{C}_{2} \mathrm{H}_{5}\right)_{3} \mathrm{SbBr}_{2}(0.31 \mathrm{~g}, 0.84 \mathrm{mmol})$ in ethanol $(1 \mathrm{~mL})$ was added. Then $\mathrm{NaHCO}_{3}(0.22 \mathrm{~g}, 2.6 \mathrm{mmol})$ and $\mathrm{Ni}\left(\mathrm{ClO}_{4}\right)_{2} \cdot 6 \mathrm{H}_{2} \mathrm{O}$ $(0.24 \mathrm{~g}, 0.65 \mathrm{mmol})$ were added to the stirring reaction mixture, which was then stirred for $4 \mathrm{~h}$ at room temperature and left overnight. The orange precipitate was filtered off, washed with diethyl ether ( $8 \mathrm{~mL}$, in two portions) and extracted with dichloromethane $(5 \mathrm{~mL})$. The extract was filtered, evaporated to half 
volume and precipitated with hexane. The precipitate was filtered off, washed with hexane and dried in vacuo. Yield: $0.45 \mathrm{~g}$ (90\%). Found (\%): C, 41.98; H, 4.64; Ni, 7.55; Sb, 15.69. Calc. for $\mathrm{C}_{27} \mathrm{H}_{36} \mathrm{~N}_{6} \mathrm{NiClO}_{7} \mathrm{Sb}(\%): \mathrm{C}, 41.94 ; \mathrm{H}, 4.66 ; \mathrm{Ni}, 7.64 ; \mathrm{Sb}$, 15.79. MS(MALDI-TOF): $m / z: 673\left[\mathrm{M}-\mathrm{ClO}_{4}{ }^{-}\right]^{+} .{ }^{1} \mathrm{H}$ NMR $\left(\mathrm{CD}_{2} \mathrm{Cl}_{2}\right): \delta$ (ppm) -23.17 (br. s, 9H, $\mathrm{CH}_{3}$ ), 1.00-3.00 (br. m, 15H, Et), 14.68 (br. s, 3H, 4-Py), 49.22 (br. s, 3H, 5-Py), 55.75 (br. s, 3H, 3-Py), 141.19 (br. s, 3H, 6-Py). ${ }^{13} \mathrm{C} \mathrm{NMR}\left(\mathrm{CD}_{2} \mathrm{Cl}_{2}\right): \delta$ (ppm) -125.77 (br. s, 2-Py), 3.16 (br. s, 6-Py), 23.91 (s, Et), 27.74 (s, Et), 118.77 (s, 4-Py), 315.98 (br. s, $\mathrm{C}=\mathrm{N}$ ), 377.65 (br. s, $\mathrm{CH}_{3}$ ), 415.01 (br. s, 3-Py), 566.40 (br. s, 5-Py). UV-vis $\left(\mathrm{CH}_{2} \mathrm{Cl}_{2}\right)$ : $\lambda_{\max }, \mathrm{nm}\left(\varepsilon \times 10^{-3}\right.$, $\mathrm{mol}^{-1} \mathrm{~L} \mathrm{~cm}^{-1}$ ): 265 (30), 307 (2.4), 319 (24), 345 (6.2), 389 (0.27), 484 (0.12), 771 (0.03), 938 (0.005).

\section{General procedure for preparation of the} metal(Iv)phthalocyaninate-capped iron and nickel(II) complexes

The corresponding metallophthalocyaninate $\left\{\mathrm{Zr}\left(\mathrm{Cl}_{2}\right) \mathrm{Pc}\right.$ or $\left.\mathrm{Hf}\left(\mathrm{Cl}_{2}\right) \mathrm{Pc}\right\}$ $(0.13 \mathrm{mmol})$, the appropriate triethylantimony-capped precursor $\left\{\left[\mathrm{Fe}(\mathrm{AcPyOx})_{3}\left(\mathrm{Sb}\left(\mathrm{C}_{2} \mathrm{H}_{5}\right)_{3}\right)\right]\left(\mathrm{ClO}_{4}\right)\right.$ or $\left.\left[\mathrm{Ni}(\mathrm{AcPyOx})_{3}\left(\mathrm{SbEt}_{3}\right)\right]\left(\mathrm{ClO}_{4}\right)\right\}$ $(0.13 \mathrm{mmol}), \mathrm{CaCO}_{3}(0.05 \mathrm{~g})$ and silica gel $(0.05 \mathrm{~g})$ were dissolved/ suspended in a dichloromethane-methanol $(3: 1)$ mixture $(4 \mathrm{~mL})$. The reaction mixture was stirred for $8 \mathrm{~h}$ at room temperature and extracted with dichloromethane. The extract was evaporated to approximately $10 \mathrm{~mL}$ and separated using column chromatography on silica gel (eluents: dichloromethane and a dichloromethaneacetone $(10: 1)$ mixture). The first eluate was thrown out, and the second eluate was collected and evaporated to dryness. The solid residue was washed with hexane and dried in vacuo.

$\left[\mathrm{Fe}(\mathrm{AcPyOx})_{3}(\mathrm{HfPc})\right]\left(\mathrm{ClO}_{4}\right)$. Yield $0.115 \mathrm{~g}(70 \%) . R_{\mathrm{f}} 0.40\left(\mathrm{SiO}_{2}\right.$, $\mathrm{CH}_{2} \mathrm{Cl}_{2}$-acetone, $\left.10: 1\right)$. Anal. calcd for $\mathrm{C}_{53} \mathrm{H}_{37} \mathrm{~N}_{14} \mathrm{O}_{7} \mathrm{FeHfCl}(\%)$ : C, 50.85; H, 2.98; N, 15.67. Found (\%): C, 50.92; H, 3.01; N, 15.70. ${ }^{1} \mathrm{H} \mathrm{NMR}\left(\mathrm{CD}_{2} \mathrm{Cl}_{2}\right): \delta(\mathrm{ppm}) 1.00\left(\mathrm{~s}, 9 \mathrm{H}, \mathrm{CH}_{3}\right), 5.80(\mathrm{~d}$, $\left.{ }^{3} J_{\mathrm{HH}}=5.42 \mathrm{~Hz}, 3 \mathrm{H}, 6-\mathrm{Py}\right), 6.67(\mathrm{~m}, 3 \mathrm{H}, 5-\mathrm{Py}), 6.97\left(\mathrm{~d},{ }^{3} J_{\mathrm{HH}}=\right.$ $8.44 \mathrm{~Hz}, 3 \mathrm{H}, 3-\mathrm{Py}), 7.41$ (m, 3H, 4-Py), 8.24 (m, 8H, $\beta-\mathrm{Pc}$ ), 9.34 $(\mathrm{m}, 8 \mathrm{H}, \alpha-\mathrm{Pc}) .{ }^{13} \mathrm{C}$ NMR $\left(\mathrm{CD}_{2} \mathrm{Cl}_{2}\right): \delta(\mathrm{ppm}) 11.53\left(\mathrm{~s}, \mathrm{CH}_{3}\right), 123.23$ (s, 3-Py), 123.76 (s, $\alpha$-Pc), 124.36 (s, 5-Py), 131.32 (s, $\beta$-Pc), 136.87 (s, 4-Py), 136.95 (s, C(Pc)), 151.53 (s, 6-Py), 153.68 (s, C=N(Pc)), $153.73(\mathrm{~s}, \mathrm{C}=\mathrm{N}(\mathrm{Pc})), 155.67(\mathrm{~s}, \mathrm{C}=\mathrm{N}), 157.38$ (s, 2-Py). MALDITOF MS: calcd for $\mathrm{C}_{53} \mathrm{H}_{37} \mathrm{~N}_{14} \mathrm{O}_{7} \mathrm{FeHfCl}$ 1252.1473; found, 1153.0602 $\left[\mathrm{M}-\mathrm{ClO}_{4}{ }^{-}\right]^{+}$. UV-vis $\left(\mathrm{CH}_{2} \mathrm{Cl}_{2}\right): \lambda_{\max }, \mathrm{nm}\left(\varepsilon \times 10^{-3}\right.$, $\mathrm{mol}^{-1} \mathrm{~L} \mathrm{~cm}^{-1}$ ): 341 (68.60), 532 (17.48); 620 (34.41); $656 \mathrm{sh}$ (29.94); 689 (218.09).

$\left[\mathrm{Fe}(\mathrm{AcPyOx})_{3}(\mathrm{ZrPc})\right]\left(\mathrm{ClO}_{4}\right)$. Yield $0.10 \mathrm{~g}(65 \%) . R_{\mathrm{f}} 0.38\left(\mathrm{SiO}_{2}\right.$, $\mathrm{CH}_{2} \mathrm{Cl}_{2}$-acetone, $\left.10: 1\right)$. Anal. calcd for $\mathrm{C}_{53} \mathrm{H}_{37} \mathrm{~N}_{14} \mathrm{O}_{7} \mathrm{FeZrCl}(\%)$ : C, 54.67; H, 3.20; N, 16.84. Found (\%): C, 54.82; H, 3.06; N, 16.96. ${ }^{1} \mathrm{H}$ NMR $\left(\mathrm{CD}_{2} \mathrm{Cl}_{2}\right): \delta(\mathrm{ppm}) 0.96\left(\mathrm{~s}, 9 \mathrm{H}, \mathrm{CH}_{3}\right), 5.84(\mathrm{~d}$, $\left.{ }^{3} J_{\mathrm{HH}}=5.45 \mathrm{~Hz}, 3 \mathrm{H}, 6-\mathrm{Py}\right), 6.68(\mathrm{~m}, 3 \mathrm{H}, 5-\mathrm{Py}), 6.97\left(\mathrm{~d},{ }^{3} J_{\mathrm{HH}}=\right.$ $8.39 \mathrm{~Hz}, 3 \mathrm{H}, 3-\mathrm{Py}$ ), 7.41 (m, 3H, 4-Py), 8.23 (m, 8H, $\beta-\mathrm{Pc}$ ), 9.34 $(\mathrm{m}, 8 \mathrm{H}, \alpha-\mathrm{Pc}) .{ }^{13} \mathrm{C} \mathrm{NMR}\left(\mathrm{CD}_{2} \mathrm{Cl}_{2}\right): \delta(\mathrm{ppm}) 11.55\left(\mathrm{~s}, \mathrm{CH}_{3}\right), 123.27$ (s, 3-Py), 123.75 (s, $\alpha$-Pc), 124.40 (s, 5-Py), 131.27 (s, $\beta$-Pc), 136.94 (s, 4-Py), 137.42 (s, C(Pc)), 151.62 (s, 6-Py), 153.94 (s, C=N(Pc)), $154.00(\mathrm{~s}, \mathrm{C}=\mathrm{N}(\mathrm{Pc})), 155.61(\mathrm{~s}, \mathrm{C}=\mathrm{N}), 158.01(\mathrm{~s}, 2-\mathrm{Py})$. MALDITOF MS: calcd for $\mathrm{C}_{53} \mathrm{H}_{37} \mathrm{~N}_{14} \mathrm{O}_{7} \mathrm{FeZrCl}, 1164.1052$; found, 1063.1984 $\left[\mathrm{M}-\mathrm{ClO}_{4}{ }^{-}\right]^{+}$. UV-vis $\left(\mathrm{CH}_{2} \mathrm{Cl}_{2}\right): \lambda_{\max }, \mathrm{nm}\left(\varepsilon \times 10^{-3}\right.$, $\mathrm{mol}^{-1} \mathrm{~L} \mathrm{~cm}^{-1}$ ): 341 (77.11), 534 (19.66), 621 (38.81), $658 \mathrm{sh}$ (34.05), 690 (245.85).
$\left[\mathrm{Ni}(\mathrm{AcPyOx})_{3}(\mathrm{HfPc})\right]\left(\mathrm{ClO}_{4}\right)$. Yield $0.120 \mathrm{~g}(73 \%) . R_{\mathrm{f}} 0.26\left(\mathrm{SiO}_{2}\right.$, $\mathrm{CH}_{2} \mathrm{Cl}_{2}$-acetone, $\left.10: 1\right)$. Anal. calcd for $\mathrm{C}_{53} \mathrm{H}_{37} \mathrm{~N}_{14} \mathrm{O}_{7} \mathrm{NiHfCl}(\%)$ : C, 50.74; H, 2.97; N, 15.63. Found (\%): C, 50.92; H, 2.92; N, 15.78. ${ }^{1} \mathrm{H}$ NMR $\left(\mathrm{CD}_{2} \mathrm{Cl}_{2}\right): \delta(\mathrm{ppm})-26.10$ (br. s, 9H, $\left.\mathrm{CH}_{3}\right), 8.22$ (m, 8H, $\beta$-Pc), 9.35 (m, 8H, $\alpha-\mathrm{Pc}$ ), 14.34 (s, 4-Py), 48.64 (br. s, 5-Py), 56.30 (br. s, 3-Py), 141.47 (br. s, 6-Py). MALDI-TOF MS: calcd for $\mathrm{C}_{53} \mathrm{H}_{37} \mathrm{~N}_{14} \mathrm{O}_{7} \mathrm{NiHfCl}$, 1254.1528; found, $1155.3228\left[\mathrm{M}-\mathrm{ClO}_{4}{ }^{-}\right]^{+}$. UV-vis $\left(\mathrm{CH}_{2} \mathrm{Cl}_{2}\right): \lambda_{\max }, \mathrm{nm}\left(\varepsilon \times 10^{-3}, \mathrm{~mol}^{-1} \mathrm{~L} \mathrm{~cm}^{-1}\right): 335$ (77.99), 352 sh (64.41), 619 (39.20), 656 sh (34.29), 688 (243.47).

$\left[\mathrm{Ni}(\mathrm{AcPyOx})_{3}(\mathrm{ZrPc})\right]\left(\mathrm{ClO}_{4}\right)$. Yield $0.121 \mathrm{~g}(79 \%) . R_{\mathrm{f}} 0.26\left(\mathrm{SiO}_{2}\right.$, $\mathrm{CH}_{2} \mathrm{Cl}_{2}$-acetone, $\left.10: 1\right)$. Anal. calcd for $\mathrm{C}_{53} \mathrm{H}_{37} \mathrm{~N}_{14} \mathrm{O}_{7} \mathrm{NiZrCl}(\%)$ : C, 54.53; H, 3.19; N, 16.80. Found (\%): C, 54.62; H, 3.25; N, 16.65. ${ }^{1} \mathrm{H}$ NMR $\left(\mathrm{CD}_{2} \mathrm{Cl}_{2}\right): \delta$ (ppm) -26.02 (br. s, 9H, $\left.\mathrm{CH}_{3}\right), 8.15$ (m, 8H, $\beta$-Pc), 9.23 (m, 8H, $\alpha$-Pc), 14.39 (s, 4-Py), 48.83 (br. s, 5-Py), 56.46 (br. s, 3-Py), 141.27 (br. s, 6-Py). MALDI-TOF MS: calcd for $\mathrm{C}_{53} \mathrm{H}_{37} \mathrm{~N}_{14} \mathrm{O}_{7} \mathrm{NiZrCl}, 1166.1055$; found, $1067.3603\left[\mathrm{M}-\mathrm{ClO}_{4}{ }^{-}\right]^{+}$. UV-vis $\left(\mathrm{CH}_{2} \mathrm{Cl}_{2}\right): \lambda_{\max }, \mathrm{nm}\left(\varepsilon \times 10^{-3}, \mathrm{~mol}^{-1} \mathrm{~L} \mathrm{~cm}^{-1}\right): 336$ (74.93), $352 \mathrm{sh}$ (59.54), 620 (36.91), $657 \mathrm{sh}$ (32.74), 688 (228.50).

\section{X-ray crystallography}

Single crystals of the $\left[\mathrm{Ni}(\mathrm{AcPyOx})_{3}\left(\mathrm{Sb}\left(\mathrm{C}_{2} \mathrm{H}_{5}\right)_{3}\right)\right]\left(\mathrm{ClO}_{4}\right),\left[\mathrm{Fe}(\mathrm{AcPyOx})_{3^{-}}\right.$ $(\mathrm{HfPc})]\left(\mathrm{ClO}_{4}\right),\left[\mathrm{Fe}(\mathrm{AcPyOx})_{3}(\mathrm{ZrPc})\right]\left(\mathrm{ClO}_{4}\right),\left[\mathrm{Ni}(\mathrm{AcPyOx})_{3}(\mathrm{HfPc})\right]\left(\mathrm{ClO}_{4}\right)$, and $\left[\mathbf{N i}(\mathbf{A c P y O x})_{3}(\mathbf{Z r P c})\right]\left(\mathbf{C l O}_{\mathbf{4}}\right)$ complexes suitable for X-ray diffraction experiments were grown at room temperature from their solutions in a dichloromethane-hexane mixture ([Ni(AcPyOx) $)_{3}$ $(\mathrm{ZrPc})],\left[\mathrm{Fe}(\mathrm{AcPyOx})_{3}(\mathrm{HfPc})\right]$ and $\left.\left[\mathrm{Ni}(\mathrm{AcPyOx})_{3}\left(\mathrm{Sb}\left(\mathrm{C}_{2} \mathrm{H}_{5}\right)_{3}\right)\right]\left(\mathrm{ClO}_{4}\right)\right)$ or in a dichloromethane-benzene mixture ([Fe(AcPyOx $\left.)_{3}(\mathbf{Z r P c})\right]$ and $\left.\left[\mathbf{N i}(\mathbf{A c P y O x})_{3}(\mathbf{H f P c})\right]\right)$. The intensities of the reflections were

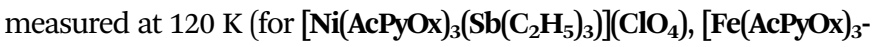
$(\mathbf{H f P c})]\left(\mathrm{ClO}_{4}\right)$, [Ni(AcPyOx $\left.)_{3}(\mathrm{HfPc})\right]\left(\mathrm{ClO}_{4}\right)$ and $\left[\mathrm{Ni}(\mathrm{AcPyOx})_{3}(\mathrm{ZrPc})\right]-$ $\left.\left(\mathbf{C l O}_{4}\right)\right)$ or at $100 \mathrm{~K}$ (for $\left.\left[\mathrm{Fe}(\mathbf{A c P y O x})_{3}(\mathbf{Z r P c})\right]\left(\mathbf{C l O}_{4}\right)\right)$ with a Bruker Apex II DUO CCD diffractometer using Mo-K $\alpha$ radiation $(\lambda=0.71073 \AA)$. The structures were solved by direct methods and refined using the full-matrix least-squares technique against $F^{2}$ in the anisotropic-isotropic approximation. Hydrogen atom positions were calculated, and they were refined in the isotropic approximation within the riding model. The unit cells of $\left[\mathrm{Ni}(\mathrm{AcPyOx})_{3}(\mathrm{ZrPc})\right]\left(\mathrm{ClO}_{4}\right)$ and $\left[\mathrm{Fe}(\mathrm{AcPyOx})_{3}(\mathbf{H f P c})\right]\left(\mathrm{ClO}_{4}\right)$ contain disordered solvent species, which were assumed to be dichloromethane and hexane, both used in the mixture for crystallization of these complexes; these species have been treated as a diffuse contribution to the overall scattering without specific atom positions by SQUEEZE/PLATON. ${ }^{22}$ All the calculations were performed with the SHELXTL program package. ${ }^{23}$

Details of data collection and refinement are given in Table S7 (see the ESI $\dagger$ ).

\section{Conclusions}

We developed a two-step synthetic pathway for new hybrid Pc-capped metal complexes by transmetallation of antimonycapped iron and nickel(II) tris-pyridineoximates with Lewis-acidic zirconium and hafnium(Iv) phthalocyaninates. They combine a transition metal clathrochelate and a phthalocyaninate complex, both of which are now used as 'building blocks' in single 
molecule magnets. The obtained hybrid complexes are therefore an important molecular platform on which new classes of these exciting materials can be built in the future.

\section{Acknowledgements}

The synthesis of the hybrid complexes was supported by the Russian Science Foundation (project 14-13-00724). Spectral and structural characterization was performed under the financial support from the Russian Foundation for Basic Research (projects 16-03-00368, 16-03-00688, 16-33-00233 and 15-29-01112) and Russian Academy of Science (program P8). Electrochemical measurements were supported by a grant from the President of the Russian Federation (projects MK-6320.2016.3 and 2179.2017.3).

\section{Notes and references}

1 (a) Y. Voloshin, I. Belaya and R. Krämer, The Encapsulation Phenomenon: Synthesis, Reactivity and Applications of Caged Ions and Molecules, Springer International Publishing, Switzerland, 2016; (b) Y. Z. Voloshin, N. A. Kostromina and R. Krämer, Clathrochelates: Synthesis, Structure and Properties, Elsevier, Amsterdam, 2002; (c) A. Ingham, M. Rodopoulos, K. Coulter, T. Rodopouls, S. Subramanian and A. McAuley, Coord. Chem. Rev., 2002, 233-234, 255-271.

2 (a) O. A. Varzatskii, I. N. Denisenko, A. S. Belov, A. V. Vologzhanina, Y. N. Bubnov, S. V. Volkov and Y. Z. Voloshin, Inorg. Chem. Commun., 2014, 44, 134-138; (b) Y. Z. Voloshin, A. S. Belov, Z. A. Starikova and A. V. Vologzhanina, Russ. Chem. Bull., Int. Ed., 2013, 62, 1858-1865; (c) O. A. Varzatskii, I. N. Denisenko, S. V. Volkov, A. S. Belov, A. V. Dolganov, A. V. Vologzhanina, V. V. Novikov, Y. N. Bubnov and Y. Z. Voloshin, Eur. J. Inorg. Chem., 2013, 3178-3184; (d) O. A. Varzatskii, S. V. Kats (Menkach), L. V. Penkova, S. V. Volkov, A. V. Dolganov, A. V. Vologzhanina, Y. N. Bubnov and Y. Z. Voloshin, Eur. J. Inorg. Chem., 2013, 1987-1992; (e) Y. Z. Voloshin, O. A. Varzatskii, A. V. Belov, Z. A. Starikova, A. V. Dolganov and T. V. Magdesieva, Polyhedron, 2007, 27, 325-334; $(f)$ Y. Z. Voloshin, O. A. Varzatskii, A. S. Belov and Y. N. Bubnov, Russ. Chem. Bull., Int. Ed., 2006, 55, 1119-1125; (g) Y. Z. Voloshin, O. A. Varzatskii, A. S. Belov, A. Y. Lebedev, I. S. Makarov, M. E. Gurskii, M. Y. Antipin, Z. A. Starikova and Y. N. Bubnov, Inorg. Chim. Acta, 2007, 360, 1543-1554.

3 (a) A. V. Dolganov, A. S. Belov, V. V. Novikov, A. V. Vologzhanina, G. V. Romanenko, Y. G. Budnikova, G. E. Zelinskii and Y. Z. Voloshin, Dalton Trans., 2015, 44, 2476-2487; (b) A. V. Dolganov, I. G. Belaya and Y. Z. Voloshin, Electrochim. Acta, 2014, 125, 302-306; (c) L. El Chachtouli, M. Fournier, S. Cherdo, R. Guillot, M.-F. Charlot, E. Anxolabéhère-Mallart, M. Robert and A. Aukauloo, J. Phys. Chem. C, 2013, 117, 17073-17077; (d) I. G. Belaya, S. V. Svidlov, A. V. Dolganov, G. E. Zelinskii, T. V. Potapova, A. V. Vologzhanina, O. A. Varzatskii, Y. N. Bubnov and Y. Z. Voloshin, Dalton Trans., 2013, 42, 13667-13678; (e) A. V. Dolganov, A. S. Belov, V. V. Novikov, A. V. Vologzhanina, A. Mokhir, Y. N. Bubnov and Y. Z. Voloshin, Dalton Trans., 2013, 42, 4373-7376; $(f)$ D. Kochubey, V. Kaichev, A. Saraev, S. Tomyn, A. Belov and Y. Voloshin, J. Phys. Chem. C, 2013, 117, 2753-2759; $(g)$ E. AnxolabéhèreMallart, C. Costentin, M. Fournier, S. Nowak, M. Robert and J.-M. Savéant, J. Am. Chem. Soc., 2012, 134, 6104-61207; (h) Y. Z. Voloshin, A. S. Belov, A. V. Vologzhanina, G. G. Aleksandrov, A. V. Dolganov, V. V. Novikov, O. A. Varzatskii and Y. N. Bubnov, Dalton Trans., 2012, 41, 6078-6093; (i) Y. Z. Voloshin, A. V. Dolganov, O. A. Varzatskii and Y. N. Bubnov, Chem. Commun., 2011, 47, 7737-7739; (j) M. T. D. Nguen, M.-F. Charlot and A. Aukauloo, J. Phys. Chem. A, 2011, 115, 911-922; (k) O. Pantani, S. Naskar, R. Guillot, P. Millet, E. Anxolabéhère-Mallart and A. Aukauloo, Angew. Chem., Int. Ed., 2008, 47, 9948-9950.

4 (a) Y. Z. Voloshin, O. A. Varzatskii, K. Y. Zhizhin, N. T. Kuznetsov and Y. N. Bubnov, Russ. Chem. Bull., Int. Ed., 2006, 55, 22-25; (b) Y. Z. Voloshin, O. A. Varzatskii, A. V. Palchik, Z. A. Starikova, M. Y. Antipin, E. G. Lebed and Y. N. Bubnov, Inorg. Chim. Acta, 2006, 359, 553-569; (c) A. B. Burdukov, E. G. Boguslavskii, V. A. Reznikov, N. V. Pervukhina, M. A. Vershinin, Y. Z. Voloshin, O. A. Varzatskii and Y. N. Bubnov, Russ. Chem. Bull., Int. Ed., 2005, 54, 1125-1130; (d) Y. Z. Voloshin, A. S. Belov, A. Y. Lebedev, O. A. Varzatskii, M. Y. Antipin, Z. A. Starikova and T. E. Kron, Russ. Chem. Bull., Int. Ed., 2004, 53, 1218-1222; (e) Y. Z. Voloshin, O. A. Varzatskii, Z. A. Starikova, M. Y. Antipin, A. Y. Lebedev and A. S. Belov, Russ. Chem. Bull., Int. Ed., 2004, 53, 1496-1502; $(f)$ Y. Z. Voloshin, O. A. Varzatskii, T. E. Kron, V. K. Belsky, V. E. Zavodnik and A. V. Palchik, Inorg. Chem., 2000, 39, 1907-1918; (g) Y. Z. Voloshin, O. A. Varzatskii, A. V. Palchik, A. I. Stash and V. K. Belsky, New J. Chem., 1999, 23, 355-358.

5 (a) Y. Z. Voloshin, V. V. Novikov and Y. V. Nelyubina, RSC Adv., 2015, 5, 72621-72637; (b) Y. Z. Voloshin, O. A. Varzatskii and Y. N. Bubnov, Russ. Chem. Bull., Int. Ed., 2007, 56, 577-605.

6 V. B. Kovalska, M. Y. Losytskyy, O. A. Varzatskii, V. V. Cherepanov, Y. Z. Voloshin, A. A. Mokhir, S. M. Yarmoluk and S. V. Volkov, Bioorg. Med. Chem., 2014, 22, 1883-1888.

7 J. Blechinger, O. A. Varzatskii, V. Kovalska, G. E. Zelinskii, Y. Z. Voloshin, E. Kinski and A. Mokhir, Bioorg. Med. Chem., 2016, 26, 626-629.

8 (a) A. A. Pavlov, Y. V. Nelubina, S. V. Kats, L. V. Penkova, N. N. Efimov, A. O. Dmitrienko, A. V. Vologzhanina, A. S. Belov, Y. Z. Voloshin and V. V. Novikov, J. Phys. Chem. Lett., 2016, 7, 4111-4116; V. V. Novikov, A. A. Pavlov, Y. N. Nelyubina, M.-E. Boulon, O. A. Varzatskii, Y. Z. Voloshin and R. E. P. Winpenny, J. Am. Chem. Soc., 2015, 137, 9792-9795; (b) V. V. Novikov, I. V. Ananyev, A. A. Pavlov, M. V. Fedin, K. A. Lyssenko and Y. Z. Voloshin, J. Phys. Chem. Lett., 2014, 5, 496-500; (c) V. V. Novikov, A. A. Pavlov, A. S. Belov, A. V. Vologzhanina, A. Savitsky and Y. Z. Voloshin, J. Phys. Chem. Lett., 2014, 5, 3799-3803.

9 (a) R. Sessoli, D. Gatteschi, A. Caneschi and M. A. Novak, Nature, 1993, 365, 141-143; (b) D. Gatteschi, R. Sessoli and 
J. Villain, Molecular nanomagnets, Oxford University Press, Oxford, 2006.

10 (a) H. Wang, B.-W. Wang, Y. Bian, S. Gao and J. Jiang, Coord. Chem. Rev., 2016, 306, 195-216; (b) K. L. M. Harriman and M. Murugesu, Acc. Chem. Res., 2016, 49, 1158-1167.

11 (a) S. V. Dudkin, N. R. Erickson, A. V. Vologzhanina, V. N. Novikov, H. V. Rhoda, C. D. Holstrom, Y. V. Zatsikha, M. S. Yusubov, Y. Z. Voloshin and V. N. Nemykin, Inorg. Chem., 2016, 55, 11867-11882; (b) Y. Z. Voloshin, O. A. Varzatskii, L. G. Tomilova, M. O. Breusova, T. V. Magdesieva, Y. N. Bubnov and R. Krämer, Polyhedron, 2007, 26, 2733-2740; (c) Y. Z. Voloshin, O. A. Varzatskii, S. V. Korobko, V. Y. Chernii, S. V. Volkov, L. A. Tomachynski, V. I. Pehn'o, V. Y. Antipin and Z. A. Starikova, Inorg. Chem., 2005, 44, 822-824; (d) J. R. Sabin, O. A. Varzatskii, Y. Z. Voloshin, Z. A. Starikova, V. V. Novikov and V. N. Nemykin, Inorg. Chem., 2012, 51, 8362-8372.

12 M. Hołyńska, Inorg. Chem. Commun., 2012, 20, 322-325.

13 (a) Y. Z. Voloshin, O. A. Varzatskii, S. V. Korobko, M. Y. Antipin, I. I. Vorontsov, K. A. Lyssenko, D. I. Kochubey, S. G. Nikitenko and N. G. Strizhakova, Inorg. Chim. Acta, 2004, 357, 3187-3204; (b) Y. Z. Voloshin, O. A. Varzatskii, A. S. Belov, Z. A. Starikova, A. V. Dolganov and T. V. Magdesieva, Polyhedron, 2008, 27, 325-334.

14 O. A. Varzatskii, L. V. Penkova, S. V. Kats (Menkach), A. V. Dolganov, A. V. Vologzhanina, A. A. Pavlov, V. V. Novikov,
A. S. Bogomyakov, V. N. Nemykin and Y. Z. Voloshin, Inorg. Chem., 2014, 53, 3062-3071.

15 (a) L. A. Tomachynski, I. N. Tretyakova, V. Y. Chernii, S. V. Volkov, M. Kowalska, J. Legendziewicz, Y. S. Gerasymchuk and S. Radzki, Inorg. Chim. Acta, 2008, 361, 2569-2581; (b) C. B. Aakeröy, A. S. Sinha, K. N. Epa, C. L. Spartz and J. Desper, Chem. Commun., 2012, 48, 11289-11291; (c) K. Isseib and B. Hamann, Z. Anorg. Allg. Chem., 1965, 339, 289-297.

16 M. Wojdyr, J. Appl. Crystallogr., 2010, 43, 1126-1128.

17 F. Neese, Wiley Interdiscip. Rev.: Comput. Mol. Sci., 2012, 2, 73-78.

18 (a) J. P. Perdew, K. Burke and M. Ernzerhof, Phys. Rev. Lett., 1996, 77, 3865-3868; (b) J. P. Perdew, K. Burke and M. Ernzerhof, Phys. Rev. Lett., 1997, 78, 1396.

19 F. Weigend and R. Ahlrichs, Phys. Chem. Chem. Phys., 2005, 7, 3297-3305.

20 C. Adamo and V. Barone, J. Chem. Phys., 1999, 110, 6158-6169.

21 S. Moon and S. Patchkovskii, in Calculation of NMR and EPR Parameters. Theory and Applications, ed. M. Kaupp, M. Bühl and V. G. Malkin, Wiley-VCH, Weinheim, Germany, 2004.

22 A. L. Spek, Acta Crystallogr., Sect. D: Biol. Crystallogr., 2009, 65, 148-155.

23 G. M. Sheldrick, Acta Crystallogr., Sect. A: Found. Crystallogr., 2008, 64, 112-122. 